\title{
FINANCIAL LIQUIDITY AND PROFITABILITY OF POLISH SELF-GOVERNING PUBLIC HEALTH CARE INSTITUTIONS IN 2016-2018
}

\author{
PŁYNNOŚĆ FINANSOWA A RENTOWNOŚĆ POLSKICH SAMORZĄDOWYCH \\ SAMODZIELNYCH PUBLICZNYCH ZAKŁADÓW OPIEKI ZDROWOTNEJ \\ W LATACH 2016-2018
}

Public Finance Department, Faculty of Economics Maria Curie-Sklodowska University in Lublin, Poland Katedra Finansów Publicznych, Wydział Ekonomiczny, Uniwersytet Marii Curie-Skłodowskiej w Lublinie

\begin{abstract}
Currently, Polish therapeutic entities are forced to operate in an extremely turbulent environment and pursue two main goals: economic and social. The aim of this article is to diagnose the relationship between profitability and financial liquidity in Polish self-government health care institutions by assessing basic indicators of financial liquidity and profitability. The scope of work covered 1017 self-government independent health care institutions, which systematically published their financial statements for 2016-2018. The subject of the study was to analyze the relationship between the levels of profitability and financial liquidity ratios. The study used statistical and tabular-descriptive methods. On the basis of the obtained results it can be stated that the relation between the return on sales, return on equity and return on assets and liquidity (current, fast and immediate) was positive and the strength of this relation was strong and statistically significant. There was a statistically significant negative correlation between short-term liabilities and the return on sales, assets and equity. The cash conversion cycle has a significant positive impact on profitability (and vice versa).

CONCLUSION. Entities that had higher profitability also had a higher degree of liquidity. They were also more efficient in inventory management and paid their liabilities faster. Summarizing the results of the study, it can be concluded that those entities that had higher profitability also had a higher degree of liquidity. They were also more efficient in inventory management and paid their liabilities faster.
\end{abstract}

Key words: liquidity, profitability, self-government independent health care units

\section{STRESZCZENIE}

Obecnie polskie podmioty lecznicze zmuszone są do działania w niezwykle dynamicznie zmieniającym się otoczeniu oraz realizują dwa główne cele: społeczny i gospodarczy. Celem niniejszego artykułu jest zdiagnozowanie zależności między rentownością a płynnością finansową w samodzielnych zakładach opieki zdrowotnej, dla których podmiotem tworzącym jest jednostka samorządu terytorialnego poprzez ocenę podstawowych wskaźników płynności finansowej i rentowności. Zakresem prac objęto 1017 samorządowych samodzielnych publicznych zakładów opieki zdrowotnej, które systematycznie publikowały swoje sprawozdania finansowe za lata 2016-2018. Przedmiotem badania była analiza relacji pomiędzy poziomami wskaźników rentowności i płynności finansowej. W opracowaniu wykorzystano metody statystyczne i tabelaryczno-deskrypcyjne. Na podstawie uzyskanych wyników można stwierdzić, że relacja pomiędzy stopą zwrotu ze sprzedaży, stopą zwrotu z kapitału własnego a stopą zwrotu z aktywów i płynnością (bieżącą, szybką i natychmiastową) była dodatnia, a siła tej relacji była silna i statystycznie istotna. Istniała istotna statystycznie ujemna korelacja pomiędzy zobowiązaniami krótkoterminowymi a poziomem zwrotu ze sprzedaży, aktywów i kapitałów własnych. Cykl konwersji gotówki ma istotny pozytywny wpływ na rentowność (i odwrotnie).

(C) National Institute of Public Health NIH - National Research Institute / Narodowy Instytut Zdrowia Publicznego PZH - Państwowy Instytut Badawczy 
WNIOSEK. Podmioty, które miały wyższą rentowność, miały wyższy stopień płynności. Były one bardziej efektywne w zarządzaniu zapasami i szybciej regulowały swoje zobowiązania.

Słowa kluczowe: płynność finansowa, rentowność, samodzielne publiczne zakłady opieki zdrowotnej

\section{INTRODUCTION}

Currently, Polish medical entities are forced to operate in an extremely turbulent, dynamically changing environment. They operate in a sector that is constantly changing due to the introduction of health care reforms, changes in financing, and the introduction of new legal provisions (1). Expenditure on the provision of medical services is increasing as life expectancy is increasing and, consequently, the number of older people increases. In addition, incurring higher and higher expenditures results from the development of medical technologies (2).

Healthcare entities pursue two most important goals: social and economic. The first one means the readiness to admit and treat patients, as well as to provide them with appropriate medical care. The second, in turn, concerns financial liquidity and profitability, despite the fact that the activity of self-government independent public health care institutions is not focused on profit maximization. The aim of managing the finances of a medical entity is to achieve the intended financial result while maintaining financial liquidity (3).

Commercial medical facilities are focused on maximizing profits, while public healthcare entities are not obliged to generate profit from their activities. However, for each of the healthcare entities, reducing of debts is one of the economic goals. The degree of achievement of the goal directly affects the method of managing the entity (4).

\section{AIM}

The aim of the study is to diagnose the relationship between profitability and liquidity in independent public health care institutions, for which the founding entity is a local government unit, by analyzing the basic indicators of financial liquidity and profitability. This paper will verify the thesis that reducing the liquidity level of an entity increases its profitability. The paper is also considering the relationship between traditional liquidity ratios and the cash conversion cycle and its components, and profitability measures.

The problem of financial liquidity management in healthcare entities has already been analyzed by many Polish and foreign authors. Among Polish researchers studying the financial liquidity of healthcare entities, it is worth paying attention to the studies by K. Prętkiwicz, P. Prętkiewicz, A. Bem and B. Krzeczewski. On the

\section{WSTĘP}

Obecnie polskie podmioty lecznicze zmuszone są do działania w niezwykle burzliwym dynamicznie zmieniającym się otoczeniu. Prowadzą działalność w sektorze, który nieustanie podlega przemianom wynikającym z wprowadzenia reform ochrony zdrowia, zmian finansowania, wprowadzenia nowych uregulowań prawnych (1). Wzrastają wydatki na świadczenia usług medycznych, ponieważ wydłuża się oczekiwana długość życia, a w związku z tym wzrasta liczba osób starszych. Ponadto ponoszenie coraz większych nakładów finansowych wynika $\mathrm{z}$ rozwoju technologii medycznych (2).

Podmioty lecznicze realizują dwa najważniejsze cele: społeczny i ekonomiczny. Pierwszy z nich oznacza gotowość przyjęcia oraz leczenia pacjenta, jak również zapewnienia mu odpowiedniej opieki medycznej. Drugi z kolei dotyczy płynności finansowej oraz rentowności, pomimo, że działalność samorządowych samodzielnych publicznych zakładów opieki zdrowotnej nie jest nastawiona na maksymalizację zysku. Celem zarządzania finansami podmiotu leczniczego jest osiąganie zamierzonego wyniku finansowego z zachowaniem płynności finansowej (3).

Komercyjne placówki medyczne nastawione są na maksymalizację zysków, z kolei publiczne podmioty lecznicze nie są zobowiązane do generowania zysku ze swojej działalności. Podmioty te za jeden z wymiarów celu ekonomicznego mają również ograniczenie lub zmniejszenie zadłużenia. Stopień osiągnięcia realizacji celu bezpośrednio wpływa na sposób zarządzania jednostką (4).

\section{CEL PRACY}

Celem badania jest zdiagnozowanie relacji między rentownością a płynnością $\mathrm{w}$ samodzielnych publicznych zakładach opieki zdrowotnej, dla których podmiotem tworzącym jest jednostka samorządu terytorialnego, poprzez analizę podstawowych wskaźników płynności finansowej i rentowności. W niniejszym artykule zostanie zweryfikowana teza, mówiąca, że zmniejszenie poziomu płynności podmiotu powoduje wzrost jego rentowności. W artykule zostaną również rozważone zależności pomiędzy tradycyjnymi wskaźnikami płynności oraz cyklem konwersji gotówki i jego składowymi a miarami rentowności.

Problem zarządzania płynnością finansową w podmiotach leczniczych był już analizowany przez wielu 
other hand, the author has not found any studies on the relationship between liquidity and profitability among independent public health care institutions, for which the founding entity is a local government unit.

The source data was the publications of the Ministry of Health, which included information on the finances of self-governmental independent public healthcare institutions for the years 2016-2018 (5).

\section{MATERIALS AND METHODS}

Independent public health care units, for which the establishing entities are voivodship, poviat and communal units of local government, were selected for the study. The data comes from the Statistical Bulletins of the Ministry of Health (Ministry of Health, Warsaw 2019). The analyzes take into account current information, i.e. collective financial statements of the entities for 2016-2018.

In the analyzed period, the number of selfgovernment independent public health care units decreased from 1072 entities in 2016 to 1017 in 2018. Most entities came from the Mazowieckie (in 2018 - 137 entities), Małopolskie (113) and Śląskie (108) voivodships.

The subjective scope of the work covered 1017 selfgoverning independent public health care institutions, which systematically published their financial statements for 2016-2018. The subject of the research was the analysis of the relationship between the levels of profitability ratios and financial liquidity. Statistical and tabular-descriptive methods are used in the work. The liquidity of an entity is the ability to settle current liabilities. The maintenance of financial liquidity by the entity does not mean the necessity to constantly dispose of such amounts of cash that would cover all liabilities. It is a derivative of having a cash surplus at the maturity of liabilities (6).

Financial liquidity will be measured using the following indicators:

- the ratio of current financial liquidity informs how many times current assets cover current liabilities (ratio of current assets to current liabilities). The higher the level of this ratio, the better the financial liquidity of the entity. The low value of the ratio indicates difficulties in overdue payments of the entity, and even insolvency. Most authors point to the model value of the current financial liquidity ratio in the range of 1.5-2.0 (7).

- quick financial liquidity ratio - the relationship between the most liquid assets (current assets less inventories and prepayments) to current liabilities. There is a belief in the literature that the standard value of this indicator is $1.0(6)$. polskich i zagranicznych autorów. Spośród badaczy polskich badających płynność finansową podmiotów leczniczych warto zwrócić uwagę na opracowania K. Prętkiewicz, P. Prętkiewicz, A. Bem i B. Krzeczewski. Natomiast Autorka nie znalazła opracowań dotyczących relacji płynności i rentowności wśród samodzielnych publicznych zakładów opieki zdrowotnej, dla których podmiotem tworzącym jest jednostka samorządu terytorialnego.

Za dane źródłowe posłużyły publikacje Ministerstwa Zdrowia uwzględniające informacje na temat finansów samorządowych samodzielnych publicznych zakładów opieki zdrowotnej za lata 2016-2018 (5).

\section{MATERIAŁ I METODY}

Do badania wytypowano samodzielne publiczne zakłady opieki zdrowotnej, których podmiotem tworzących są wojewódzkie, powiatowe i gminne jednostki samorządu terytorialnego. Dane pochodzą z Biuletynów Statystycznych Ministerstwa Zdrowia (Ministerstwo Zdrowia, Warszawa 2019). W analizach uwzględnione zostały aktualne informacje, czyli zbiorcze sprawozdania finansowe jednostek $\mathrm{z}$ lat 2016-2018.

W badanym okresie liczba samorządowych samodzielnych publicznych zakładów opieki zdrowotnej zmniejszyła się z 1072 podmiotów w 2016 r do poziomu 1017 w 2018 r. Najwięcej podmiotów pochodziło z województwa mazowieckiego (w 2018 r. - 137 podmiotów), małopolskiego (113) i śląskiego (108).

Zakres podmiotowy pracy objął 1017 samorządowych samodzielnych publicznych zakładów opieki zdrowotnej, które systematycznie publikowały za lata 2016-2018 swoje sprawozdania finansowe. Przedmiotem badań była analiza zależności między poziomami wskaźników rentowności a płynności finansowej. W pracy wykorzystano metody statystyczne i tabelaryczno-opisowe.

Płynność podmiotu jest to zdolność do regulowania bieżących zobowiązań. Utrzymanie przez podmiot płynności finansowej nie oznacza konieczności ciągłego dysponowania takimi kwotami środków pieniężnych, które pokrywałaby w całości zobowiązania. Jest pochodną posiadania nadwyżki pieniężnej w terminach zapadalności zobowiązań (6).

Płynność finansowa będzie mierzona za pomocą następujących wskaźników:

- wskaźnik bieżącej płynności finansowej informuje ile razy aktywa obrotowe pokrywają bieżące zobowiązania (relacja aktywów obrotowych do zobowiązań bieżących). Im wyższy poziom tego wskaźnika, tym lepsza płynność finansowa podmiotu. Niska wartość wskaźnika świadczy o trudnościach płatniczych jednostki, a nawet o nie- 
- immediate financial liquidity ratio - the ratio of cash to current liabilities. The value of this ratio should range between 0.1 and 0.2 . This indicator describes the payment capacity of the entity. It also expresses the company's ability to conduct speculative transactions.

- inventory conversion cycle - the average time needed to manufacture and sell final goods from raw materials and materials. This indicator also tells you about the number of days an entity replenishes its inventory to make a specific sale. Its high value is the result of low inventory turnover (inventories ratio to daily net sales) (8).

- receivables conversion cycle - the average time needed to convert receivables into cash, i.e. to obtain cash from sales. This ratio determines how long the entity freezes its capital in receivables. The higher its value, the more lenient the credit policy is applied by the entity towards its clients, or it proves the ineffective functioning of the receivables management unit. Similarly, the short period of debt collection is the result of a restrictive lending policy (the ratio of receivables to daily net sales) (8).

- liability conversion cycle - the average time between the purchase of materials and services and the payment for these materials. This ratio determines how long an entity's operations are credited by suppliers (ratio of current liabilities to daily net sales) (9).

On the other hand, the profitability ratios of an entity measure the entity's ability to generate profit. They are also supposed to inform about the possibilities of increasing the owners' wealth. These indicators show the cumulative impact of liquidity, asset management and debt management on the company's performance (9).

Profitability will be measured by the following indicators:

- return on sales (ROS) - is the percentage of profit to sales revenues. It tells you what amount of net profit is generated by the unit sales amount. The lower the value of this ratio, the more sales must be made in order to achieve the same amount of profit (6).

- return on equity (ROE) - informs about the amount of net profit generated by the unit amount of invested equity of the enterprise. The growing level of the return on equity ratio proves the higher efficiency of capital employed in its various forms (6).

- return of assets (ROA) - it is the ratio of profit to total assets. It informs about the amount of profit generated by the unit of capitals involved in the activity of the enterprise. For a positive assessment wypłacalności. Większość autorów wskazuje na wzorcową wartość wskaźnika bieżącej płynności finansowej w granicach 1,5-2,0 (7).

- wskaźnik szybkiej płynności finansowej - jest to relacja najbardziej płynnych składników majątkowych (aktywa obrotowe pomniejszone o zapasy i rozliczenia międzyokresowe czynne) do zobowiązań bieżących. W literaturze panuje przekonanie, że wzorcowa wartość tego wskaźnika wynosi 1,0 (6).

- wskaźnik natychmiastowej płynności finansowej - relacja środków pieniężnych do zobowiązań bieżących. Wartość tego wskaźnika powinna wahać się w przedziale 0,1-0,2. Wskaźnik ten opisuje zdolności płatnicze podmiotu. Wyraża także zdolność przedsiębiorstwa do przeprowadzania transakcji spekulacyjnych.

cykl konwersji zapasów - przeciętny czas potrzebny na wytworzenie dóbr finalnych $\mathrm{z}$ surowców i materiałów i sprzedaż tych wyrobów. Wskaźnik ten informuje również o tym, co ile dni jednostka odnawia swoje zapasy w celu zrealizowania określonej sprzedaży. Jego wysoka wartość jest rezultatem wolnego obrotu zapasami (relacja zapasów odniesiona do dziennej sprzedaży netto) (8).

cykl konwersji należności - przeciętny czas potrzebny na przekształcenie należności w środki pieniężne tj. na uzyskanie środków pieniężnych ze sprzedaży. Wskaźnik ten określa jak długo podmiot zamraża swój kapitał w należnościach. Im większa jest jego wartość, tym łagodniejszą politykę kredytową prowadzi jednostka wobec swoich klientów, albo świadczy to o nieefektywnym funkcjonowaniu komórki zarządzającej należnościami. Analogicznie krótki okres ściągania należności jest wynikiem restrykcyjnej polityki kredytowej (relacja należności do dziennej sprzedaży netto) (8).

- cykl konwersji zobowiązań - przeciętny czas między nabyciem materiałów i usług a zapłatą za te materiały. Wskaźnik ten określa jak długo działalność podmiotu jest kredytowana przez dostawców (relacja zobowiązań bieżących do dziennej sprzedaży netto) (9).

Natomiast wskaźniki rentowności jednostki mają za zadanie pomiar zdolności podmiotu do generowania zysku. Mają także informować o możliwościach wzrostu majątku właścicieli. Wskaźniki te pokazują kumulatywny wpływ płynności, zarządzania aktywami i zarządzania długiem na wyniki działalności przedsiębiorstwa (9).

Rentowność będzie mierzona za pomocą następujących wskaźników:

wskaźnik rentowności sprzedaży (ROS) - są stosunkiem procentowym zysku do przychodów ze 
of the company's activity, it is desirable to increase its value (6).

Since profitability and financial liquidity are interrelated and mutually conditioned, the Pearson's linear correlation coefficient was used to investigate the relationship between these phenomena, which is a standard measure of the strength and direction of linear interdependence of two measurable features.

An appropriate significance test was used for the computed correlation coefficients. For this purpose, the null hypothesis was formulated about the lack of correlation between the variables:

$\mathrm{H}_{0}: \rho x y=0$, against the alternative hypothesis that such a correlation exists $\mathrm{Hj}: \rho x{ }^{\wedge} 0$ (two-sided critical value). As a result of testing the significance of the correlation coefficient, the probabilities $\mathrm{p}$ ( $\mathrm{p}$-value) related to the calculated values of the test function are determined. By comparing the $\mathrm{p}$-value with the adopted significance level $\alpha=$ e.g. 0.0522 , the statistical significance of the correlation coefficients is assessed. When $\mathrm{p}$ is $<0.05$, the null hypothesis is rejected, which means that the relationship between the variables is statistically significant.

\section{RESULTS}

In the years 2016-2018, a systematic increase in revenues and costs of self-governmental public health care institutions in Poland was observed. In 2016, total revenues amounted to PLN 29.7 billion, and in 2018 they were higher by $11.9 \%$ and amounted to PLN 33.3 billion. The highest revenues in 2018 were generated by entities in the Mazowieckie voivodship and amounted to PLN 4.1 billion, while the lowest revenues were in 2018 in the Lubuskie Voivodship and amounted to PLN 361 million. The highest increase in revenues in the analyzed period was noticed in the Małopolskie Voivodship by $18.4 \%$, while in the Opolskie Voivodship a decrease in revenues by $21.7 \%$ was noticed.

Total costs in the same period increased by $14.2 \%$ and amounted to PLN 34.3 billion in 2018. The highest level of costs in 2018 was recorded in the healthcare entities in the Mazowieckie Voivodship and they amounted to PLN 4.3 billion in 2018, the lowest level of costs can be observed in the Lubuskie Voivodship and in 2018 they amounted to PLN 368 million. The highest increase in costs in the analyzed period was recorded in the Podlaskie Voivodship by $20.3 \%$, while in the Opolskie Voivodship there was a decrease in costs by $21.1 \%$.

The financial result of self-government independent public healthcare institutions in the analyzed period deteriorated from PLN 318 million in 2016 to PLN 1 billion in 2018. The most loss-generating entities are sprzedaży. Informuje on jaką kwotę zysku netto generuje jednostkowa kwota sprzedaży. Im niższa jest wartość tego wskaźnika, tym większą sprzedaż należy zrealizować, chcąc osiągnąć tę samą kwotę zysku (6).

- wskaźnik rentowności kapitałów własnych (ROE) - informuje, jaką kwotę zysku netto generuje jednostkowa kwota zainwestowanego kapitału własnego przedsiębiorstwa. Rosnący poziom wskaźnika rentowności kapitału własnego świadczy o wyższej efektywności zaangażowanego kapitału w różnych jego formach (6).

- wskaźnik rentowności majątku ogółem (ROA) jest to relacja zysku do aktywów ogółem. Informuje on o kwocie zysku generowanej przez jednostkę zaangażowanych $\mathrm{w}$ działalność przedsiębiorstwa kapitałów. Dla pozytywnej oceny działalności przedsiębiorstwa pożądanych jest jego wzrost wartości (6).

Ponieważ rentowność i płynność finansowa są ze sobą powiązane i wzajemnie warunkują się, do zbadania zależności między tymi zjawiskami wykorzystano współczynnik korelacji liniowej Pearsona, który stanowi unormowany miernik siły i kierunku współzależności liniowej dwóch cech mierzalnych.

Dla obliczonych współczynników korelacji zastosowano odpowiedni test istotności. W tym celu została sformułowana hipoteza zerowa o braku korelacji między zmiennymi:

$\mathrm{H}_{0}: \rho x y=0$, wobec hipotezy alternatywnej, że taka korelacja istnieje $\mathrm{Hj}: \rho x y^{\wedge} 0$ (dwustronny obszar krytyczny). W wyniku testowania istotności współczynnika korelacji wyznaczone są prawdopodobieństwa $p$ ( $p$-value) związane z obliczonymi wartościami funkcji testowej. Przez porównanie wartości p z przyjętym poziomem istotności $\alpha=$ np. 0,0522 ocenia się statystyczną istotność współczynników korelacji. Gdy p jest $<0,05$, to odrzuca się hipotezę zerową, co oznacza, że związek między zmiennymi jest statystycznie istotny.

\section{WYNIKI}

W latach 2016-2018 obserwowano systematyczny wzrost przychodów i kosztów samorządowych samodzielnych publicznych zakładów opieki zdrowotnej w Polsce. W 2016 r. przychody ogółem wyniosły 29,7 mld zł, a w 2018 r. były wyższe o 11,9\% i wyniosły 33,3 mld zł. Największe przychody w 2018 r. uzyskały podmioty w województwie mazowieckim i wyniosły 4,1 mld zł, najniższe zaś przychody były w 2018 r. w województwie lubuskim i wyniosły $361 \mathrm{mln}$ zł. Największy przyrost przychodów w badanym okresie zauważono w województwie małopolskim o $18,4 \%$, natomiast $\mathrm{w}$ województwie opolskim zauważono spadek przychodów o $21,7 \%$. 
in the Ślaskie Voivodship, where their loss in 2018 amounted to a total of PLN 165 million, the smallest losses are generated by entities in the Pomeranian Voivodship (net result in 2018 was - PLN 3 million).

The Pearson linear correlation coefficient calculated for profitability and financial liquidity (its levels and the cash conversion cycle and its components) is shown in Table 1.

Table 1. Pearson's linear correlation coefficients Tabela 1. Współczynniki korelacji liniowej Pearsona

\begin{tabular}{|c|c|c|c|c|}
\hline \multirow{9}{*}{ 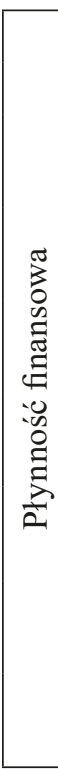 } & \multirow{2}{*}{ Zmienne } & \multicolumn{3}{|c|}{ Rentowność } \\
\hline & & $\mathrm{ROA}$ & ROE & ROS \\
\hline & Bieżąca & $\begin{array}{c}0,8651 \\
p=0,000\end{array}$ & $\begin{array}{c}0,8588 \\
p=0,000\end{array}$ & $\begin{array}{c}\mathbf{0 , 8 6 0 4} \\
p=0,000\end{array}$ \\
\hline & Szybka & $\begin{array}{c}0,8589 \\
p=0,000\end{array}$ & $\begin{array}{c}0,8495 \\
p=0,000\end{array}$ & $\begin{array}{c}0,8554 \\
p=0,000\end{array}$ \\
\hline & Natychmiastowa & $\begin{array}{c}0,8190 \\
p=0,000\end{array}$ & $\begin{array}{c}0,8065 \\
p=0,000\end{array}$ & $\begin{array}{c}0,8186 \\
p=0,000\end{array}$ \\
\hline & $\begin{array}{l}\text { Cykl konwersji } \\
\text { zapasów }\end{array}$ & $\begin{array}{c}0,2124 \\
p=0,425\end{array}$ & $\begin{array}{c}0,2548 \\
p=0,341\end{array}$ & $\begin{array}{c}0,1325 \\
p=0,625\end{array}$ \\
\hline & $\begin{array}{l}\text { Cykl konwersji } \\
\text { należności }\end{array}$ & $\begin{array}{l}-0,1004 \\
p=0,712\end{array}$ & $\begin{array}{l}-0,1053 \\
p=0,698\end{array}$ & $\begin{array}{c}-0,1817 \\
p=0,501\end{array}$ \\
\hline & $\begin{array}{l}\text { Cykl konwersji } \\
\text { zobowiązań }\end{array}$ & $\begin{array}{l}-0,6940 \\
p=0,003\end{array}$ & $\begin{array}{l}-0,7082 \\
p=0,002\end{array}$ & $\begin{array}{c}-0,7447 \\
p=0,001\end{array}$ \\
\hline & $\begin{array}{l}\text { Cykl konwersji } \\
\text { gotówki }\end{array}$ & $\begin{array}{c}0,7252 \\
p=0,001\end{array}$ & $\begin{array}{c}0,7422 \\
p=0,001\end{array}$ & $\begin{array}{c}0,7266 \\
p=0,001\end{array}$ \\
\hline
\end{tabular}

On the basis of the obtained results, it can be concluded that the relationship between return on sales and financial liquidity (current, quick and immediate) was positive and the strength of this relationship was strong and statistically significant.

The relationship between the return on sales and the inventory turnover rate was positive, statistically insignificant, while the relationship between the receivables turnover rate was negative, statistically insignificant. Healthcare entities, which turned over their inventories more slowly and shortened the period of payment of receivables by recipients, had a higher profitability of sales.

The units that paid off their short-term liabilities faster were characterized by higher profitability of sales. This means that the longer conversion cycle of short-term liabilities results from financial difficulties than from the willingness to take advantage of the positive impact, i.e. lower costs related to shortterm liabilities, especially since in most entities this profitability was negative.

The positive relationship between the return on sales and the cash conversion cycle (statistically significant) shows that in organizations the longer the time from the outflow of cash due to the settlement of
Koszty ogółem w analogicznym okresie wzrosły o 14,2\% i wyniosły w 2018 r. 34,3 mld zł. Najwyższy poziom kosztów w 2018 r. odnotowano w jednostkach w województwie mazowieckim i wyniosły one w 2018 r. 4,3 mld zł, najmniejszy poziom kosztów zauważyć można w województwie lubuskim i wyniosły one w 2018 r. 368 mln zł. Najwyższy wzrost kosztów w badanym okresie odnotowano w województwie podlaskim 0 20,3\%, zaś w województwie opolskim odnotowano spadek kosztów o 21,1\%.

Wynik finansowy samorządowych samodzielnych publicznych zakładów opieki zdrowotnej w badanym okresie uległ pogorszeniu z poziomu $-318 \mathrm{mln}$ zł w 2016 r. do poziomu - 1 mld zł w 2018 r. Najbardziej stratne są jednostki w województwie śląskim, gdzie ich strata w 2018 r. wyniosła łącznie $165 \mathrm{mln}$ zł, najmniejsze straty przynoszą podmioty w województwie pomorskie (wynik netto w 2018 r. wyniósł - $3 \mathrm{mln}$ zł).

Współczynnik korelacji liniowej Pearsona obliczone dla rentowności i płynności finansowej (jej poziomów oraz cyklu konwersji gotówki i jego składowych) zawiera Tabela 1.

Na podstawie uzyskanych wyników można stwierdzić, że zależność między rentownością sprzedaży a płynnością finansową (bieżącą, szybką i natychmiastową) była dodatnia i siła tego związku była silna $\mathrm{i}$ istotna statystycznie.

Zależność między rentownością sprzedaży a szybkością rotacji zapasów była dodatnia, nieistotna statystycznie, zaś między szybkością rotacji należności była ujemna, nieistotna statystycznie. Podmioty lecznicze, które wolniej obracały zapasami i skracały okres spłaty należności przez odbiorców, miały wyższą rentowność sprzedaży.

Jednostki, które szybciej spłacały swoje zobowiązania krótkoterminowe, cechowała wyższa rentowność sprzedaży. Oznacza to, że dłuższy cykl konwersji zobowiązań krótkoterminowych wynika $\mathrm{z}$ trudności finansowych niż z chęci skorzystania z pozytywnego oddziaływania, tj. niższych kosztów związanych ze zobowiązaniami krótkoterminowymi, zwłaszcza, że w większości podmiotów rentowność ta była ujemna.

Dodatnia zależność między rentownością sprzedaży a cyklem konwersji gotówki (istotna statystycznie) pokazuje, że w organizacjach im dłuższy czas jaki upływa od momentu odpływu środków pieniężnych w związku z regulowaniem zobowiązań do momentu wpływu środków pieniężnych z tytułu inkasowania należności, tym rentowność sprzedaży jest wyższa.

Istnieje dodatnia, istotna zależność między rentownością majątku a poziomami płynności finansowej.

Im szybszy był obrót zapasami, im szybsza spłata zobowiązań, tym rentowność majątku była wyższa. Ale tylko wpływ zobowiązań krótkoterminowych okazał się statystycznie istotny, podobnie jak w przy- 
liabilities to the moment of cash inflow from collection of receivables, the higher the profitability of sales.

There is a positive, significant relationship between asset profitability and financial liquidity levels.

The faster the turnover of inventories, the faster the repayment of liabilities, the higher the profitability of assets. But only the impact of short-term liabilities turned out to be statistically significant, as in the case of the cash conversion cycle - the (positive) relationship was significant.

The relationship between return on equity and financial liquidity turned out to be positive and statistically significant. The impact of the inventory conversion cycle was positive and the receivables conversion cycle negative, but statistically insignificant. The impact of the current liabilities conversion cycle on the return on equity was negative, and of the cash conversion cycle - positive and statistically significant.

Each element of the cash conversion cycle had a different impact on profitability. The existence of a statistically significant, negative correlation relationship between short-term liabilities and the profitability of sales, assets and equity proves that liability management has a greater impact on profitability than in the case of inventory and receivables management, where the correlation relationship is weaker and insignificant. The cash conversion cycle has a significant, positive impact on profitability (and vice versa).

\section{DISCUSSION}

The entity's ability to settle its short-term liabilities on an ongoing basis depends, among other things, on the amount of funds involved in the most liquid assets (i.e. cash and short-term securities). The more an entity maintains liquid assets, the greater its ability to settle its current liabilities in a timely manner. However, the low level of surplus liquid assets does not mean that the entity will experience problems with the current settlement of liabilities. The regular inflow of cash to the entity enables the current settlement of liabilities without the need to maintain surplus cash and short-term securities. In such a situation, liquidity is maintained (10).

A diagnosis of financial liquidity also requires a careful analysis of the life cycle. Appropriate turnover of individual assets and capitals is one of the conditions for ensuring financial efficiency. Therefore, the conversion cycles for inventories, receivables and liabilities are calculated. By adding up the inventory and receivable conversion cycle and subtracting the liability conversion cycle, you get the cash conversion cycle. It is the period from the outflow of cash from the entity to obtaining revenues from the sale of products padku cyklu konwersji gotów - zależność (dodatnia) była istotna.

Związek między rentownością kapitału własnego a płynnością finansową okazał się dodatni i istotny statystycznie. Wpływ cyklu konwersji zapasów był dodatni a cyklu konwersji należności ujemny, ale nieistotny statystycznie. Wpływ cyklu konwersji zobowiązań bieżących na rentowność kapitału własnego był ujemny a cyklu konwersji gotówki - dodatni $\mathrm{i}$ istotny statystycznie.

Każdy element cyklu konwersji gotówki w różnym stopniu wpływał na rentowność. Istnienie statystycznie istotnej, ujemnej, zależności korelacyjnej między zobowiązaniami krótkoterminowymi a poziomem rentowności sprzedaży, majątku i kapitału własnego świadczy o tym, że zarządzanie zobowiązaniami ma większy wpływ na rentowność niż w przypadku zarządzania zapasami i należnościami, gdzie zależność korelacyjna ma charakter słabszy i nieistotny. Cykl konwersji gotówki ma istotny, dodatni wpływ na kształtowanie się rentowności (i odwrotnie).

\section{DYSKUSJA}

Zdolność jednostki do bieżącego regulowania zobowiązań krótkoterminowych zależy między innymi od ilości środków zaangażowanych w najbardziej płynne aktywa (tj. gotówkę i krótkoterminowe papiery wartościowe). Im więcej podmiot utrzymuje płynnych aktywów, tym większa jest jego zdolność do terminowego regulowania zobowiązań bieżących. Jednakże niski poziom nadwyżek płynnych aktywów nie świadczy o tym, że w podmiocie wystąpią problemy z bieżącym regulowaniem zobowiązań. Regularny dopływ środków pieniężnych do jednostki umożliwia bieżące regulowanie zobowiązań bez konieczności utrzymywania nadwyżek środków pieniężnych i krótkoterminowych papierów wartościowych. W takiej sytuacji płynność finansowa zostaje zachowana (10).

Diagnoza dotycząca płynności finansowej wymaga także dokładnej analizy cyklu eksploatacyjnego. Odpowiednia rotacja poszczególnych składników aktywów i kapitałów jest jednym z warunków zapewnienia sprawności finansowej. Dlatego też oblicza się cykle konwersji zapasów, należności i zobowiązań. Przez zsumowanie cyklu konwersji zapasów i należności i odjęcie cyklu konwersji zobowiązań uzyskuje się cykl konwersji gotówki. Jest to okres od wypływu środków pieniężnych z podmiotu do uzyskania przychodów ze sprzedaży produktów i usług. Im on jest krótszy, tym większa sprawność finansowa podmiotu.

Rentowność rozumiana jako zdolność do generowania zysku jest jednym z kluczowych czynników warunkujących osiąganie celów finansowych w jednostce. Dążeniu do uzyskiwania przychodów przewyż- 
and services. The shorter it is, the greater the financial efficiency of the entity.

Profitability, understood as the ability to generate profit, is one of the key factors determining the achievement of financial goals in an entity. Striving to obtain revenues exceeding costs should also be accompanied by care for maintaining financial liquidity, i.e. the ability to pay current liabilities.

One of the main factors influencing financial profitability is profit, however, its increase is not always accompanied by an increase in liquidity (arrears with payments, loan sales), and an increase in profitability does not necessarily mean an improvement in financial liquidity. There is a wide range of indicators measuring profitability that allow you to make decisions related to the management of an entity. These ratios include return on assets, return on sales, and return on equity.

Liquidity management affects the profitability or value of the entity (depending on what financial goal the entity adopts). There is a negative relationship between liquidity and profitability, i.e. an increase in liquidity leads to a decrease in the goodwill (or its profitability) and vice versa. However, this dependence is not so obvious in all conditions. In general, a reduction in financial liquidity (by reducing the level of current assets and / or increasing the share of current liabilities) leads to an increase in profitability, but this only happens up to a certain point. Due to the functions performed by current assets, as well as the negative consequences related to the excessive share of short-term liabilities, lowering the liquidity below a certain level results not in an increase, but a decrease in profitability (11).

Achieving high profitability comes at the expense of higher risk, which is associated not only with the possibility of loss of financial liquidity, but also the occurrence of other phenomena that have a negative impact on the functioning of the entity.

The nature of the relationship between profitability and liquidity depends on the period in which it is considered $(12,13)$. The dominant view in the literature is that in the short run there is a negative relationship between these categories (substitution of liquidity and profitability).

In the long term, profit as a source of additional, free cash flows increases the organization's ability to settle liabilities, i.e. an increase in profitability has a positive effect on the improvement of its solvency (14). The nature and direction of the profitability and liquidity relationships also depend on their level. For small values of liquidity, its increase also causes an increase in the level of profitability. Once the cutoff point is reached, profitability stops responding to the increase in liquidity. For high liquidity values, its further increase causes a decrease in profitability szających koszty powinno towarzyszyć także dbanie o utrzymanie płynności finansowej, czyli zdolności do regulowania zobowiązań bieżących.

Jednym z głównych czynników wpływających na rentowność finansową jest zysk, jednakże nie zawsze jego wzrostowi towarzyszy zwiększenie płynności (zalegania z płatnościami, sprzedaż na kredyt), a wzrost rentowności niekoniecznie oznacza poprawę płynności finansowej. Można wyróżnić szeroką gamę wskaźników mierzących rentowność, które pozwalają na podejmowanie decyzji związanych z zarządzaniem podmiotem. Do tych wskaźników zaliczamy rentowność aktywów, rentowność sprzedaży, rentowność kapitału własnego.

Zarządzanie płynnością finansową wpływa na rentowność lub wartość jednostki (w zależności od tego, jaki cel finansowy przyjmie jednostka). Istnieje ujemny związek między płynnością a rentownością, tj. wzrost płynności finansowej prowadzi do spadku wartości firmy (lub jej rentowności) i odwrotnie. Jednak zależność ta nie w każdych warunkach jest tak oczywista. Generalnie obniżenie płynności finansowej (poprzez zmniejszenie poziomu aktywów obrotowych i/lub zwiększenie udziału zobowiązań bieżących) prowadzi do wzrostu zyskowności, ale dzieje się tak tylko do pewnego momentu. Z uwagi na funkcje, jakie pełnią aktywa obrotowe, jak również negatywne konsekwencje związane ze zbyt dużym udziałem zobowiązań krótkoterminowych, obniżenie płynności poniżej pewnego poziomu skutkuje nie wzrostem, ale spadkiem zyskowności (11).

Uzyskanie wysokiej rentowności następuje kosztem wyższego ryzyka, które związane jest nie tylko z możliwością utraty płynności finansowej, ale również wystąpieniem innych, negatywnie wpływających na funkcjonowanie podmiotu zjawisk.

Charakter zależności pomiędzy rentownością i płynnością zależy od okresu w jakim jest ona rozpatrywana $(12,13)$. W literaturze dominuje pogląd, że w krótkim okresie występuje negatywna relacja pomiędzy tymi kategoriami (substytucja płynności i rentowności).

W długim okresie zysk jako źródło dodatkowych, wolnych przepływów pieniężnych zwiększa zdolność organizacji do regulowania zobowiązań, czyli wzrost rentowności pozytywnie oddziałuje na poprawę jego wypłacalności (14). Charakter i kierunek relacji rentowności i płynności zależy także od ich poziomu. Dla małych wartości płynności jej wzrost powoduje także zwiększenie poziomu rentowności. Po osiągnięciu wartości granicznej rentowność przestaje reagować na wzrost płynności. Dla wysokich wartości płynności dalszy jej wzrost powoduje spadek rentowności (15). Jose, Lancaster i Stevens używają w swoich badaniach zarówno ROA, jak i ROE w celu rozróżnienia rentow- 
(15). Jose, Lancaster, and Stevens use both ROA and ROE in their research to distinguish between return related to asset management (ROA) and profitability related to entity financing (ROE).The higher the value of the above ratios, the better for the entity, therefore a positive correlation between them and the company's liquidity should be expected. In the relationship between liquidity and profitability, the shaping of the operating cycle and the cash conversion cycle are of significant importance (13). The increase in current assets causes an increase in liquidity, and if the total assets do not change, then there is a decrease in the value of fixed assets, which means that the ROA will not change. However, when an increase in current assets causes a simultaneous increase in total assets, it will entail changes in liabilities and so an increase in profit (which increased cash) will theoretically increase ROA, but one should note that at the same time total assets increase, so it is not to be expected. An increase in current liabilities with a simultaneous increase in current assets will not cause a change in liquidity, but a decrease in ROA, and an increase in long-term debt in the absence of changes in equity (and vice versa) will cause the ROA to decrease. At the same time, a decrease in current liabilities will increase ROA if current assets remain unchanged and the value of fixed assets decreases. This situation will not affect the return on equity. As for ROE, an increase in profit will increase its current liabilities and will not have an impact on the return on equity in the same way as an increase in debt. However, considering changing the financing structure by increasing debt, one should bear in mind the financial costs which reduce profit and thus profitability. When it comes to return on equity, it is strongly dependent on profit and financing structure. If current liabilities decrease (liquidity increases), but at the same time equity increases, ROE will decrease, and when long-term debt increases, the costs of its servicing will increase, profit will decrease, which may also have a negative impact on ROE. Other liquidity ratios are related to their increasing level (13).

The way in which an entity manages working capital, as measured by the length of the cash conversion cycle, affects the profitability of the entity.

Current assets by changing their form from monetary to tangible and from tangible to monetary, participate in the process of generating profit. The faster the transformation processes take place, the less capital will have to be involved in the production process, which will contribute to an increase in its profitability (15).

The analysis of the relationship between profitability and liquidity in local government hospitals shows that in the medical entities sector there is no characteristic relationship between financial liquidity and profitability. ności związanej z zarządzaniem aktywami (ROA) i rentowności związanej z finansowaniem podmiotu (ROE). Im wyższa wartość powyższych wskaźników tym lepiej dla jednostki, dlatego należy oczekiwać dodatniej korelacji między nimi a płynnością firmy. W relacjach pomiędzy płynnością rentownością istotne znaczenie ma kształtowanie się cyklu operacyjnego i cyklu konwersji gotówki (13). Wzrost aktywów bieżących powoduje wzrost płynności, a jeśli aktywa razem nie zmieniają się, wówczas mamy do czynienia ze spadkiem wartości aktywów trwałych, co powoduje, że ROA się nie zmieni. Jednak, gdy wzrost aktywów bieżących spowoduje jednoczesny wzrost aktywów razem, pociągnie to za sobą zmiany w pasywach i tak wzrost zysku (który zasilił gotówkę) spowoduje teoretycznie wzrost ROA, ale należy pamiętać, że jednocześnie rosną aktywa razem, więc nie należy się go spodziewać. Wzrost w zobowiązaniach bieżących przy jednoczesnym wzroście aktywów bieżących nie spowoduje zmiany w płynności tylko spadek ROA, a wzrost długu długoterminowego przy braku zmian w kapitale własnym (i odwrotnie) spowoduje, że ROA zmaleje. Jednocześnie zmniejszenie zobowiązań bieżących spowoduje wzrost ROA, jeżeli aktywa bieżące pozostaną bez zmian, a zmniejszy się wartość aktywów trwałych. Sytuacja ta nie wpłynie na rentowność kapitałów własnych. Jeśli chodzi o ROE to wzrost zysku spowoduje jego wzrost zobowiązań bieżących i nie będzie miał wpływu na rentowność kapitałów własnych tak, jak wzrost długu. Jednak, biorąc pod uwagę zmianę struktury finansowania poprzez zwiększenie długu, należy pamiętać o kosztach finansowych, które zmniejszają zysk, a przez to rentowność. Jeśli chodzi o rentowność kapitałów własnych to jest on silnie uzależniony od zysku i struktury finansowania. Jeżeli zobowiązania bieżące zmaleją (podniesie się płynność), ale wzrośnie jednocześnie kapitał własny, to ROE spadnie, a gdy wzrośnie dług długoterminowy, wzrosną koszty jego obsługi, spadnie zysk, co też może mieć negatywny wpływ na ROE. Inne wskaźniki płynności są związane z coraz wyższym ich poziomem (13).

Sposób, w jaki podmiot zarządza kapitałem obrotowym, którego miarą jest długość cyklu konwersji gotówki, wpływa na rentowność podmiotu.

Aktywa obrotowe, zmieniając swoją postać z pieniężnej na rzeczową i z rzeczowej na pieniężną, uczestniczą w procesie tworzenia zysku. Im szybciej będą następowały procesy transformacji, tym mniej kapitału będzie trzeba zaangażować w procesie produkcyjnym, co przyczyni się do wzrostu jego rentowności (15).

Analiza związku rentowności i płynności w szpitalach samorządowych pokazuje, że w sektorze podmiotów leczniczych nie występuje charakterystyczna 
Typically, a decrease in financialliquidity is accompanied by an increase in profitability. However, the situation in the analyzed entities is different. Hospitals that maintained higher levels of financial liquidity achieved higher levels of profitability. This thesis has also been proven by other authors who conducted research on individual medical entities (16).

\section{CONCLUSIONS}

There is a relationship between the level of profitability and financial liquidity in the case of polish self-governing public healthcare institutions.

This positive relationship is due to the fact that hospitals operating as independent public health care units cannot go bankrupt. Therefore, despite many financial difficulties, such hospitals must continue to function, and the responsibility for their functioning rests with the establishing organs.

When summarizing the results of the research, it can be stated that those self-government independent health care units with higher profitability also had a higher degree of financial liquidity. They were also more efficient in managing inventories and they also paid their liabilities faster.

Due to the basic goal of the medical entities, which is the patients' well-being and saving their health and life, the self-government hospital sector cannot be expected to maximize profits, and thus high profitability levels. Areas where improvements can be made should be searched for in order for the entities to operate efficiently.

\section{REFERENCES}

1. Karkowski T. Restrukturyzacja Szpitali. Warszawa: Wolters Kluwer Polska; 2012:82.

2. Raulinajtys-Grzybek M. Zarządzanie kosztami podmiotów leczniczych: rola i zadania pielęgniarek. Warszawa: Wolters Kluwer Polska; 2013:13.

3. Romanowska M, Kowalik J. Ocena kondycji finansowej sektora ochrony zdrowia. Studia i Prace WNEIZ US 2017; 47/1:252.

4. Wielicka-Gańczarczyk K. Problematyka stosowania wskaźników ekonomicznych w ocenie kondycji finansowe podmiotów leczniczych. Zeszyty Naukowe Politechniki Śląskiej, Organizacja i Zarządzanie 2015:506.

5. Biuletyny Statystyczne Ministerstwa Zdrowia, Warszawa 2019, 2018, 2017.

6. Jaworski J. Teoria i praktyka zarządzania finansami przedsiębiorstw. Warszawa: Wydawnictwo CeDeWu; 2010:150-165.

7. Siemińska E. Metody pomiaru i ocen kondycji finansowej przedsiębiorstwa. Toruń: TNOiK; 2002: 56-66. relacja między płynnością finansową a rentownością. Zazwyczaj spadkowi płynności finansowej towarzyszy wzrost rentowności. Jednak $\mathrm{w}$ analizowanych podmiotach sytuacja jest odmienna. Szpitale, które zachowywały wyższe poziomy płynności finansowej uzyskiwały wyższe poziomy rentowności. Teza ta została też udowodniona przez innych Autorów, którzy prowadzili badania na pojedynczych podmiotach leczniczych (16).

\section{WNIOSKI}

Istnieje zależność między poziomem rentowności i płynności finansowej w przypadku polskich samorządowych samodzielnych publicznych zakładów opieki zdrowotnej. Ta dodatnia relacja wynika $\mathrm{z}$ tego, że szpitale funkcjonujące $\mathrm{w}$ formie samodzielnych publicznych zakładów opieki zdrowotnej nie mogą upaść. Pomimo więc wielu trudności finansowych takie szpitale muszą funkcjonować dalej, a odpowiedzialność za ich funkcjonowanie spoczywa na organach tworzących.

Podsumowując wyniki badań, można stwierdzić, że te samorządowe samodzielne zakłady opieki zdrowotnej, które miały wyższą rentowność, posiadały też wyższy stopień płynności finansowej. Cechowała je również większa sprawność w zarządzaniu zapasami i szybciej spłacały one także swoje zobowiązania.

Ze względu na podstawowy cel, jaki przyświeca działalności podmiotów leczniczych, jakim jest dobro pacjenta i ratowanie jego zdrowia i życia, to od sektora szpitali samorządowych nie można oczekiwać maksymalizacji zysków, a co się z tym wiąże wysokich poziomów rentowności. Należy poszukiwać obszarów, w których da się wprowadzić usprawnienia, aby podmioty działały w wydajny sposób.

8. Karpuś P. Zarządzanie finansami w przedsiębiorstwie. Lublin: Wydawnictwo UMCS w Lublinie; 2007:110-120.

9. Michalski G. Wprowadzenie do zarządzania finansami przedsiębiorstw. Warszawa: Wydawnictwo C.H. Beck; 2010; 22.

10. Wawryszuk-Misztal A. Zależność między zarządzaniem kapitałem obrotowym netto a rentownością na przykładzie spółek notowanych na Giełdzie Papierów Wartościowych w Warszawie. Annales UMCS sec. H 2007; XLI.. 279.

11. Bolek M, Wolski R. Wpływ płynności na rentowność przedsiębiorstwa, Studia Prawno-Ekonomiczne 2010; LXXXXI:219 - 233. 
12. Bolek M, Grosicki B. Związek wzrostu przedsiębiorstwa $\mathrm{z}$ poziomem płynności $\mathrm{w}$ spółkach o profilu innowacyjnym i tradycyjnym na GPW. Finanse, Rynki Finansowe, Ubezpieczenia 2013; 766 (62): 497-504.

13. Waściński T, Kruk M. Analiza powiązań pomiędzy rentownością i płynnością spółek branży cukierniczej notowanych na GPW. Zeszyty Naukowe Akademii Podlaskiej w Siedlcach. Administracja i Zarządzanie 2010; 84: 9-20.

14. Jaworski J, Czerwonka L, Mądra-Sawicka M. Zależność między rentownością a płynnością finansową $\mathrm{w}$ sektorze przetwórstwa spożywczego w Polsce. Roczniki Naukowe Stowarzyszenia Ekonomistów Rolnictwa i Agrobiznesu Roczniki Naukowe SERIA 2018; XX (1):58-63.

15. Wawryszuk-Misztal A. Strategie zarządzania kapitałem obrotowym netto w przedsiębiorstwie. Lublin: Wydawnictwo UMCS 2007: 80 -102
16. Krzeczewski B. Finanse szpitali w Polsce. Strategie płynności. Łódź; Wydawnictwo Uniwersytetu Łódzkiego; 2020.

Received: 22.12.2020

Accepted for publication: 02.09.2021

Otrzymano: 22.12.2020 r.

Zaakceptowano do publikacji: 02.09.2021 r.

Address for correspondence:

Adres do korespondencji:

dr Magdalena Jaworzyńska

Katedra Finansów Publicznych, Wydział Ekonomiczny Uniwersytet Marii Curie-Skłodowskiej w Lublinie Pl. M. Curie-Skłodowska 5, 20-031 Lublin

e-mail:mjawor@hektor.umcs.lublin.pl

tel: 517380615 